\title{
COMPARATIVE STUDY OF THE HAEMAGGLUTINATION TEST AND A SIMPLE LATEX-FIXATION TEST FOR THE DETECTION OF THE RHEUMATOID FACTOR
}

\author{
BY \\ G. MORGAN \\ Prince of Wales's General Hospital, London
}

The exact nature of the "rheumatoid factor" is unknown, but it appears to be an antibody-like substance composed of a gamma globulin complex of high molecular weight. Two groups of tests have been used to detect it: the haemagglutination test and the latex-fixation or Bentonite flocculation test. In the first group the indicator consists of sheep red cells with rabbit anti-sheep haemolysin as the reactant. In the second group the indicators are either polystyrene latex particles or bentonite particles with gamma globulin as the reactant. In both groups of tests the indicator becomes sensitized or coated with reactant which then reacts with sera containing the rheumatoid factor, causing agglutination of the indicator.

In the following series of 176 cases, serum from each case was examined for the rheumatoid factor, using a standard haemagglutination test and a simple slide latex-fixation test.

\section{Methods \\ (A) Haemagglutination Test \\ Reagents \\ (1) Sheep red cells. \\ (2) Rabbit anti-sheep haemolytic serum.}

Doubling dilutions of rabbit anti-sheep haemolytic serum were incubated at $37^{\circ} \mathrm{C}$. for 1 hour with equal quantities of a 1 per cent. suspension in saline of sheep red cells. After a further hour at room temperature the agglutination end-point was read. Then a 1 per cent. solution of sheep red cells was sensitized with haemolytic serum (agglutination titre previously determined). After $30 \mathrm{~min}$. equal quantities of doubling dilutions of a patient's serum (previously decomplemented at $56^{\circ} \mathrm{C}$. for $30 \mathrm{~min}$.) were incubated for 1 hour at $37^{\circ} \mathrm{C}$. with equal quantities of the sensitized sheep cells. As a control, the patient's serum was also incubated at the same time with unsensitized sheep cells.

After a further hour at room temperature, if the agglutination titre of the sensitized cells to unsensitized cells exceeded 16, the test was considered positive.
(B) Latex-Fixation Test

\section{Reagents}

(1) Latex-globulin reagent (indicator already coated with reactant).

(2) Positive control serum.

(3) Negative control serum.

(4) Glycine-saline buffer diluent (adjusted to simplify preparation of diluted serum).

A $1: 20$ dilution of serum in glycine-saline buffer diluent was made. One drop of this was placed on ad slide and to it was added one drop of latex globulin reagent. These were mixed with a stick and the slideco was gently tilted from side to side for $1 \mathrm{~min}$. Sera con-c taining the rheumatoid factor produced visible floccutaition of the reagent, and a smooth suspension indicated a negative reaction. Positive and negative controls were carried out. The results of the test were read as follows :Oㄱ

$\begin{array}{ll}\text { Negative } & \begin{array}{l}\text { No visible flocculation as } \\ \text { shown by negative control. }\end{array} \\ \text { Weakly Positive }(+) & \begin{array}{l}\text { Visible flocculation with } \\ \text { small aggregates. }\end{array} \\ \text { Strongly Positive }(++) & \begin{array}{l}\text { Visible flocculation with lar- } \\ \text { ger aggregates and a clear } \\ \text { background as shown by } \\ \text { positive control. }\end{array}\end{array}$

\section{Results}

The results in the 176 persons tested are shown in Table I (opposite). The 100 cases classed as rheumatoid arthritis satisfied the accepted diagnostic criteria.을 The fifteen "suspected" cases were under obser-? vation as ones which might develop into rheumatoido arthritis, but it has not been possible to carry out a follow-up on this group.

Table I shows that 89 per cent. of the rheumatoid arthritis group gave positive results in the latexfixation test, while the haemagglutination test 0 carried out in parallel was positive in 74 per cent Two out of fifteen "suspected" cases gave positive results in the latex-fixation test, and one in the haemagglutination test. Three out of six cases of disseminated lupus erythematosus gave positive ${ }^{-}$ 
TABLE I

RESULTS IN 176 SERA

\begin{tabular}{|c|c|c|c|c|c|c|c|c|c|c|}
\hline \multirow{2}{*}{$\begin{array}{l}\text { Test .. } \\
\text { Result }\end{array}$} & \multirow{2}{*}{$\frac{\cdots}{\cdots}$} & \multirow{2}{*}{$\cdots$} & \multirow{2}{*}{$\cdots$} & \multirow{2}{*}{$\cdots$} & \multirow{2}{*}{$\cdots$} & \multirow{2}{*}{$\cdots$} & \multicolumn{2}{|c|}{ Haemagglutination } & \multicolumn{2}{|c|}{ Latex-Fixation } \\
\hline & & & & & & & Positive & Negative & Positive & Negative \\
\hline \multirow{5}{*}{ Diagnosis } & \multicolumn{5}{|c|}{ Rheumatoid Arthritis (100) } & $\cdots$ & 74 & 26 & 89 & 11 \\
\hline & \multicolumn{6}{|c|}{ Suspected Rheumatoid Arthritis (15) } & 1 & 14 & 2 & 13 \\
\hline & \multicolumn{6}{|c|}{ Disseminated Lupus Erythematosus (6) } & 3 & 3 & $\mathbf{0}$ & 6 \\
\hline & \multicolumn{4}{|c|}{ Other Diseases* (45) } & $\cdots$ & $\cdots$ & $\mathbf{0}$ & 45 & $\mathbf{0}$ & 45 \\
\hline & \multicolumn{4}{|c|}{ Normal Controls (10) } & $\ldots$ & $\ldots$ & 0 & 10 & 0 & 10 \\
\hline
\end{tabular}

- Osteo-arthritis (13), Gout (4), Rheumatic fever (8), Scleroderma (1), Erythema multiforme (1), Other diseases (18, including Pyelitis, Hypochromic anaemia, Pernicious anaemia, Gastric ulcer, and Bronchitis).

results in the haemagglutination test, but all the latex-fixation results were negative. It is apparent that the latex-fixation test is more sensitive and more specific for rheumatoid arthritis. No false positive results were given in this series.

Singer and Plotz (1956) described the latexfixation test performed in tubes. This involved maintaining the constancy of the latex concentration, the make and source of the gamma globulin used, the time of incubation and temperature, and a borate buffer at $\mathrm{pH} 8.2$ for optimal conditions for the test in rheumatoid arthritis. A series of tests gave the results shown in Table II.

A comparison of the latex test and the sheep cell agglutination test gave the results shown in Table III.
It may be concluded that in the present series of cases the slide latex test was superior in that it gave 89 per cent. positive results in rheumatoid arthritis as compared with the 71.3 per cent. obtained by Singer and Plotz. The probable reason for this is that the present reagents are superior to and more stable than those used by Singer and Plotz.

Bozicevich, Bunim, Freund, and Ward (1958) have described a Bentonite flocculation test for rheumatoid arthritis. The test consists of coating Bentonite particles with human gamma globulin. When mixed with the serum of patients with rheumatoid arthritis, flocculation occurs. In a series of 41 cases, 78 per cent. gave positive results. In a control series, including cases of rheumatic disease

TABLE II

LATEX TEST

\begin{tabular}{|c|c|c|c|c|c|c|c|c|c|c|}
\hline \multirow{2}{*}{\multicolumn{8}{|c|}{ Diagnosis }} & \multirow{3}{*}{$\frac{\text { No. of Cases }}{150}$} & \multicolumn{2}{|c|}{ Positive Results } \\
\hline & & & & & & & & & \multirow{2}{*}{$\frac{\text { Number }}{107}$} & \multirow{2}{*}{$\frac{\text { Percentage }}{71 \cdot 3}$} \\
\hline Rheumatoid Arthritis & $\cdots$ & $\cdots$ & $\cdots$ & $\cdots$ & $\cdots$ & $\cdots$ & $\cdots$ & & & \\
\hline \multicolumn{3}{|c|}{ Osteo-arthritis and Other Arthritis } & $\cdots$ & $\cdots$ & $\cdots$ & $\cdots$ & $\cdots$ & 250 & 5 & 2 \\
\hline \multicolumn{5}{|c|}{ Rheumatic Fever and Rheumatic Heart Disease } & $\cdots$ & $\cdots$ & $\cdots$ & 250 & 4 & $1 \cdot 6$ \\
\hline Hyperglobulinaemia & . & $\cdots$ & $\cdots$ & . & $\cdots$ & $\cdots$ & $\cdots$ & 80 & 4 & 5 \\
\hline \multicolumn{3}{|c|}{ Disseminated Lupus Erythematosus } & $\cdots$ & $\cdots$ & . & $\cdots$ & $\cdots$ & 20 & 1 & 5 \\
\hline \multicolumn{2}{|c|}{ Other Cases (Non-Articular) } & $\cdots$ & $\cdots$ & $\cdots$ & $\cdots$ & $\cdots$ & $\cdots$ & 560 & 17 & 3 \\
\hline Normal Subjects & $\cdots$ & .. & . & $\ldots$ & . & $\ldots$ & $\ldots$ & 200 & 2 & 1 \\
\hline
\end{tabular}

TABLE III

COMPARISON OF LATEX TEST WITH SHEEP CELL AGGLUTINATION TEST

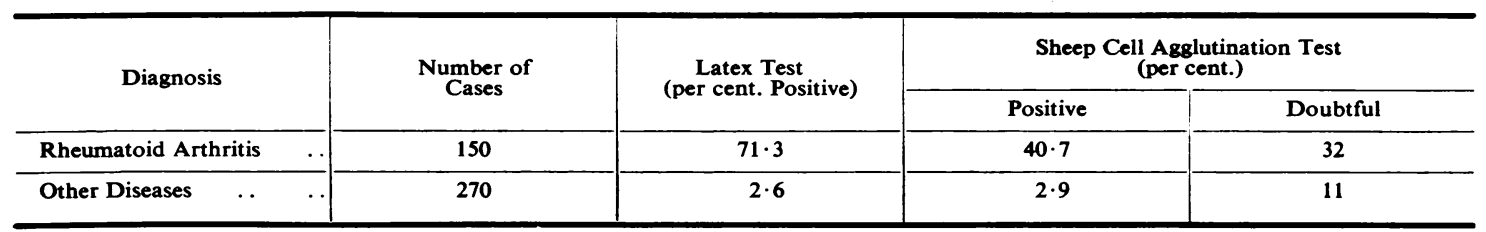


other than rheumatoid arthritis (Rheumatic Heart Disease, Gout, Systemic Lupus Erythematosus, Rheumatic Fever), carcinoma, and other conditions, 2 per cent. gave positive results, i.e. one case of systemic lupus erythematosus, one case of brain tumour with macroglobulinaemia, and one case of acute leukaemia. A series of tests on normal people all gave negative results. In the above series of cases sera tested by the sheep cell agglutination test and the Bentonite flocculation test showed agreement in 98 per cent. From these results it can be concluded that the latex test is superior to the Bentonite flocculation test in rheumatoid arthritis since only 78 per cent. were positive as compared with 89 per cent. in the present series.

\section{Summary}

176 persons (115 with rheumatoid disease and 6 with disseminated lupus erythematosus) were examined for the rheumatoid factor, using a standard haemagglutination test and a simple latex-fixation test. It is concluded that the latex-fixation test is simple and time-saving, and superior to the former test.
I should like to thank Dr. W. I. Leslie for his advice and Dr. J. H. Glyn for his clinical help.

The reagents for the latex-fixation test were supplied? by the Hyland Laboratories, California, U.S.A.

\section{REFERENCES}

Bozicevich, J., Bunim, J. J., Freund, J., and Ward, S. B. (1958) Proc. Soc. exp. Biol. (N.Y.), 97, 180.

Singer, J. M., and Plotz, C. M. (1956). Amer. J. Med., 21, 888.

Etude comparée de la réaction d'hémagglutination et d'unē simple réaction de fixation sur latex pour déceler le facteur rhumatismal

\section{RÉSUMÉ}

On rechercha le facteur rhumatismal chez 176 per-sonnes (dont 115 atteintes de maladie rhumatismale y $6 \vec{\omega}$ de lupus érythémateux disséminé) au moyen de laō réaction d'hémagglutination habituelle et d'une simplệ réaction de fixation sur latex. On conclut que lậ réaction de fixation sur latex est simple, rapide et supérieure à la première reaction.

Estudio comparativo de la reacción de hemaglutinación ycu un simple test de fijación sobre latex para descubrir el factor reumatoide

\section{Sumario}

Se buscó el factor reumatoide en 176 personas (115 con artritis reumatoide y 6 con lupus eritematoso diseminado) usando la reacción de hemaglutinación clásica y un simple test de fijación sobre latex. Se concluye que eB test de fijación sobre latex es sencillo, rápido y superior a lą믐 reación mencionada. 